\title{
APRESENTAÇÃO
}

Fiel aos seus escopos, o segundo número da Revista do NESEF Filosofia e Ensino apresenta ao seu público um conjunto de reflexões plurais acerca de dois temas que, no campo vasto e contraditório da educação filosófica, constituem-se em relação de complementaridade, a saber: as diversas expressões que o exercício do pensamento filosófico pode assumir e aspectos da formação e da prática da docência da filosofia.

Mais uma vez nosso Conselho Editorial procurou contemplar trabalhos de intelectuais experientes e com longas carreiras docente e acadêmica e produções de pesquisadores que estão no início de seu percurso profissional e de pesquisa. Os artigos, por um lado, contemplam diferentes perspectivas de pesquisa e de estudos acerca do ensino de filosofia de diversos estados e regiões do país e, por outro, expressam o enraizamento e engajamento filosófico local enquanto resultado da reflexão coletiva.

A pluralidade de matrizes epistemológicas deste número, no entanto, não significa a defesa de posições relativistas por parte do NESEF, instituição de pesquisa social e educação que, há vários anos, procura combinar a defesa da inscrição própria da filosofia na forma escolar a uma práxis política, cuja expressão coletiva e pública é, segundo entendemos, condição para as filosofias que se pretendem ir além de um debate analítico entre especialistas.

Agradecemos a todos que, de alguma maneira, colaboraram com esta edição, especialmente aos autores, conselheiros e membros do coletivo do NESEF. Por fim, não poderíamos deixar de mencionar e agradecer aos professores de filosofia da educação básica, sobretudo aos que realizam sua tarefa docente nas escolas públicas. São estes profissionais que, nos últimos anos, têm ampliado e, propriamente, publicizado - com todas as limitações e contingências inerentes à educação básica brasileira mantida e gerida pelo estado - o debate de ideias e a construção de autonomias, ao desafiarem-se cotidianamente a problematizar filosoficamente a realidade vivida e pensada com os grandes contingentes de jovens e adultos que acorrem à educação pública.

\section{Saudações filosóficas.}

Ana Carolina Mallmann

Geraldo Balduíno Horn

Valéria Arias 